\title{
Simple Electrochemical Synthesis of Pyrazolo[4,3-c]quinoline Derivatives
}

\author{
SARAH FAHAD ALAJMI', TAMER EZZAT YOUSSEF ${ }^{2,3 *}$ \\ ${ }^{1}$ Department of Chemistry, University College at Nairiyah, University of Hafr Al Batin, Nairiyah 31981, Saudi Arabia \\ ${ }^{2}$ Department of Chemistry, College of Science, Imam Abdulrahman Bin Faisal University, P.O. Box 1982, Dammam 31441, \\ Saudi Arabia \\ ${ }^{3}$ Basic and Applied Scientific Research Center, Imam Abdulrahman Bin Faisal University, P.O. Box 1982, Dammam 31441, \\ Saudi Arabia
}

\begin{abstract}
Valuable pyrazolo[4,3-c]quinoline derivatives were synthesized efficiently from the easily available 7-Chloro-4-hydrazinoquinoline through electrochemical synthesis under moderate and scalable electrolytic conditions afforded linear hydrazones (3a-g) then the cyclized one (4a-g). The conduct of the reactions was performed in a simple undivided cell under constant current without oxidizing reagents or transition metal catalysts. The synthesized products of the cyclization reaction have been characterized via UV/Vis spectrophotometry, IH-NMR and FTIR spectroscopy, the understanding of the mechanism of the reaction, the importance of reactant structure to control the rate of the reaction and equilibria in the process is substantial. The applying of this protocol to the effective synthesis of key intermediates for antidiabetic compounds was done.
\end{abstract}

Keywords: Green chemistry, Quinoline, Heteroaromatic, Organic electrosynthesis

\section{Introduction}

Organic electrosynthesis (OES) is considered a versatile technique since it is a technique which has environmentally friendly nature; moreover, it is classified as a clean and green procedure. OES method overcomes the conventional processes whether organic synthesis or synthetic via many advantages, such as mild reaction conditions, higher yield, higher products selectivity, easy to control process [1-4]. In recent times, OES has become increasingly popular due to the progress made in the field and development of relevant technology which allows an increasing number of chemical methodologies [5, 6]. Besides the increased safety and improvements in multistep synthesis, advantages such as improved mixing and heat management, energy efficiency, scalability, waste generation, access to a wider range of reaction condition, and reproducibility potential benefit of green chemistry [7].

Nowadays, this technique is more commonly used to prepare a series of heterocyclic compounds such as Imidazoquinolines, benzothiazoles [8-10].

Quinoline and their derivatives are an important category of heterocycles, they used as beneficial dyes and intermediates in organic synthesis. Furthermore, they are used to make rubber and chemicals [11].

They have more substantial biological activities and pharmacological properties such as anticancer [12-14], fungicidal [15], anti-malarial [16], anti-leishmanial [17], antibacterial [18], anticonvulsant [19]. In addition, they possess antitumor activity studies [20].

Great attention has been concentrated on the synthesis of quinoline derivatives such as their hydrazone derivatives in the last years because they are possessed advantageous biological activities. Quinoline hydrazone derivatives used as antimicrobial [21], antifungal agents [22], anti-tubercular [23], anti-tumoral [24], and anti-leishmanial [25], they can be prepared by traditional methods of synthesis from the reaction of arene aldehydes [26, 27], with quinoline hydrazine derivatives.

*email: temoustafa@iau.edu.sa 
In a continuation of our previous work [28], In 1999, Youssef's group reported the electrochemical reduction of some 2,4-disubstituted pyridines. After a long gap, we report herein for the first time, the design of a novel electrochemical reactor and its application in the cyclic hydrazones formation via the electrochemical reaction of heteroaromatic hydrazines when they react with aromatic aldehydes to give the cyclic heteroaromatic hydrazones, by using an undivided cell.

\section{Materials and methods \\ Materials and reagents}

All reagents used were of the highest purity available. 7-Chloro-4-hydrazinoquinoline (99.0\% purity) was purchased from Sigma-Aldrich, while benzaldehyde, 4-dimethylaminobenzaldehyde, 2-trifluoromethoxybenzaldehyde, 4-nitrobenzaldehyde,4-methoxybenzaldehyde, $p$-tolualdehyde, and 2-chlorobenzaldehyde were purchased from Fluka (99.0\% purity). The supporting electrolyte tetrabutylammonium tetrafluoroborate (TBATFB) 99\%.

\section{Cell and electrode design}

The controlled potential organic electrosynthesis experiments were conducted in an undivided cell and in constant current of $5 \mathrm{~mA}$ and were equipped with two electrodes. They were a graphite electrode ( $\phi 6 \mathrm{~mm}$, about $10 \mathrm{~mm}$ immersion depth in solution) and a platinum plate electrode $(10 \mathrm{~mm} \times 10 \mathrm{~mm} \times 0.2$ $\mathrm{mm})$ as the anode and the cathode, respectively.

\section{Instruments}

A Stuart SMP30 apparatus was used to determine melting points via open capillary tubes, and they were uncorrected. Thin-layer chromatography (TLC) was the technique that used to monitor the progress of all reactions and determine the purity of all compounds performed on aluminum foil sheets, and these sheets were precoated by adsorbent material as silica gel 60 F254 with a thickness of $0.20 \mathrm{~mm}$ (Merck plates)while the visualization was done via ultraviolet radiation $(254 \mathrm{~nm})$. The measurements of $1 \mathrm{H}$ NMR spectra were conducted on an NMR spectrometer device (Bruker Avance II, $300 \mathrm{MHz}$ ) and were recorded in deuterated solvent that was dimethyl sulfoxide-d6 (DMSO-d6) contained in tetramethylsilane (TMS). Chemical shifts $(\delta)$ were reported in ppm downfield proportional to tetramethylsilane (TMS, $\delta=0 \mathrm{ppm}$ ); moreover, the peak of the residual proton of the solvent (DMSO-d6) appeared at $\delta=$ $2.53 \mathrm{ppm}$. The measurements of mass spectrometric were carried out by the Shimadzu LC-MS/MS 8050 spectrometer operating at $70 \mathrm{eV}$ and were reported in mass/charge $(\mathrm{m} / \mathrm{z})$. The measurements of UV-Vis spectra were performed on an Agilent $8453 \mathrm{UV}-\mathrm{Vis}$ spectrophotometer using dimethyl formamide (DMF). IR spectra were recorded on an FTIR spectrophotometer (Shimadzu, IR Affinity 1, Tokyo). A Vario MICRO-cube Elementar (Elemental Analyzer, Germany) was used to conduct the microanalysis for C, H, and N. All spectra were recorded in Imam Abdulrahman Bin Faisal University facility.

\section{General procedure for the organic electrosynthesis of 7-chloro-1H-pyrazolo[4,3-c]quinoline derivatives (4a-g)}

The crude 7-chloro-4-hydrazinoquinolines (5; $0.6 \mathrm{mmol})$, aldehydes 2a-g and MeCN (10 $\mathrm{mL})$ were added in a $150 \mathrm{~mL}$ undivided cell; moreover, this mixture was stirred at room temperature or heated until TLC showed that condensation was done. Next, Tetrabutylammonium tetrafluoroborate (TBATFB) $(0.5 \mathrm{mmol})$ was added and followed by $\mathrm{MeCN}(5 \mathrm{~mL})$ and $\mathrm{H}_{2} \mathrm{O}(1 \mathrm{~mL})$. Meanwhile, the cell was equipped with a graphite electrode as the anode $(\phi 6 \mathrm{~mm}$, about $10 \mathrm{~mm}$ immersion depth in solution) and a platinum plate electrode as the cathode $(10 \mathrm{~mm} \times 10 \mathrm{~mm} \times 0.2 \mathrm{~mm})$. The entire mixture was stirred and electrolyzed under a constant current of $10 \mathrm{~mA}$ for 20-30 min. The reaction mixture was transported to a single-necked flask after the reaction was finished; therefore, the $\mathrm{MeCN}$ was removed by rotary evaporation. Then, the remains of the mixture were washed and extracted with water and $\mathrm{CH}_{2} \mathrm{Cl}_{2}(10$ $\mathrm{mL}$ x 3), respectively. The organics were combined, dehydrated over $\mathrm{Na}_{2} \mathrm{SO}_{4}$, and concentrated. The 
obtaining of the desired products $\mathbf{4 a - g}$ with high purity was achieved by flash column chromatography on silica gel.

\section{7-chloro-3-phenyl-1H-pyrazolo[4,3-c]quinoline (4a)}

Prepared from 2a as a pale green solid; m.p. $224-234^{\circ} \mathrm{C} ; \mathrm{Rf}=0.7 ; \mathrm{IR}(\mathrm{KBr}): \mathrm{v}=3400 \mathrm{~cm}^{-1}(\mathrm{~N}-\mathrm{H}$ stretching), $3000 \mathrm{~cm}^{-1}$ (C-H aromatic stretching), weak overtone peaks at $2000 \mathrm{~cm}^{-1}$ (Mono substituted phenyl), $1600 \mathrm{~cm}^{-1}$ ( $\mathrm{C}=\mathrm{N}$ stretching), $1450 \mathrm{~cm}^{-1}$ ( $\mathrm{C}=\mathrm{C}$ aromatic stretching), $1350 \mathrm{~cm}^{-1}$ ( $\mathrm{C}-\mathrm{H}$ bending), $1200 \mathrm{~cm}^{-1}$ (C-N stretching), $1100 \mathrm{~cm}^{-1}$ (C=C-H bending), Two strong bands at 750 and $690 \mathrm{~cm}^{-1}$ (Mono substituted), $550 \mathrm{~cm}^{-1}$ (C-Cl stretching) ${ }^{1} \mathrm{H}-\mathrm{NMR}\left(126 \mathrm{MHz}, \mathrm{DMSO}-\mathrm{d}^{6}\right): \delta=8.47(1 \mathrm{H} ; 2), 7.91(2 \mathrm{H}$; 5\&6), $7.82(1 \mathrm{H} ; 8), 7.70(1 \mathrm{H} ; \mathrm{o}), 7.51(1 \mathrm{H} ; \mathrm{m}), 7.23(1 \mathrm{H} ; \mathrm{p}) \mathrm{ppm}$. UV-Vis (DMF): $\lambda_{\max }(\mathrm{nm}): 373,368,361$ nm. MS (EI): $\mathrm{m} / \mathrm{z}=279.72\left(\mathrm{M}^{+}\right)$. Elemental analysis: $\mathrm{C}_{16} \mathrm{H}_{10} \mathrm{~N}_{3} \mathrm{Cl}$; Found $\mathrm{C} 67.20, \mathrm{H} 3.10, \mathrm{~N} 14.12$, Calc. C 68.70, H 3.60, N 15.02.

\section{7-chloro-3-(p-tolyl)-1H-pyrazolo[4,3-c]quinoline (4b)}

Prepared from $2 \mathrm{~b}$ as a brown solid; m.p. $210-212^{\circ} \mathrm{C} ; \mathrm{Rf}=0.9 ; \mathrm{IR}(\mathrm{KBr}): \mathrm{v}=3416 \mathrm{~cm}^{-1}(\mathrm{~N}-\mathrm{H}$ stretching), $3010 \mathrm{~cm}^{-1}$ (C-H aromatic stretching), $2900 \mathrm{~cm}^{-1}\left(\mathrm{CH}_{3}\right.$ stretching), 4 weak overtone peaks at $2000 \mathrm{~cm}^{-1}$ (mono substituted phenyl), $1610 \mathrm{~cm}^{-1}$ ( $\mathrm{C}=\mathrm{N}$ stretching), $1460 \mathrm{~cm}^{-1}(\mathrm{C}=\mathrm{C}$ aromatic stretching), $1360 \mathrm{~cm}^{-1}$ (C-H bending), $1230 \mathrm{~cm}^{-1}$ (C-N stretching), $1156 \mathrm{~cm}^{-1}$ (C-C stretching), $1116 \mathrm{~cm}^{-1}(\mathrm{C}=\mathrm{C}-\mathrm{H}$ (bending), One strong band at $813 \mathrm{~cm}^{-1}$ (para-di-substituted), $554 \mathrm{~cm}^{-1}$ (C-Cl stretching); ${ }^{1} \mathrm{H}-\mathrm{NMR}(126$ MHz, DMSO-d $\left.{ }^{6}\right): \delta=8.36(1 \mathrm{H} ; 2), 7.81(2 \mathrm{H} ; 5 \& 6), 7.67(1 \mathrm{H} ; 8), 7.54(1 \mathrm{H} ; \mathrm{o}), 7.30(1 \mathrm{H} ; \mathrm{m}), 2.34(3 \mathrm{H} ; \mathrm{p})$ ppm. UV-Vis (DMF): $\lambda_{\max }(\mathrm{nm}): 375,370,363 \mathrm{~nm}$. MS (EI): $\mathrm{m} / \mathrm{z}=293.75\left(\mathrm{M}^{+}\right)$. Elemental analysis: $\mathrm{C}_{17} \mathrm{H}_{12} \mathrm{~N}_{3} \mathrm{Cl}$; Found C 69.98, H 3.90, N 13.90, Calc. C 69.51, H 4.12, N 14.30.

\section{7-chloro-3-(4-methoxyphenyl)-1H-pyrazolo[4,3-c]quinolone (4c)}

Prepared from $2 \mathrm{c}$ as a pale brown solid; m.p. $175-195^{\circ} \mathrm{C} ; \mathrm{Rf}=0.76 ; \mathrm{IR}(\mathrm{KBr}): \mathrm{v}=3423 \mathrm{~cm}^{-1}(\mathrm{~N}-\mathrm{H}$ stretching), $3011 \mathrm{~cm}^{-1}$ (C-H aromatic stretching), $2930 \mathrm{~cm}^{-1}\left(\mathrm{CH}_{3}\right.$ stretching), 4 weak overtone peaks at $2000 \mathrm{~cm}^{-1}$ (mono substituted phenyl), $1605 \mathrm{~cm}^{-1}$ ( $\mathrm{C}=\mathrm{N}$ stretching), $1454 \mathrm{~cm}^{-1}$ ( $\mathrm{C}=\mathrm{C}$ aromatic stretching), $1352 \mathrm{~cm}^{-1}$ (C-H bending), $1253 \mathrm{~cm}^{-1}$ (C-O stretching), $1210 \mathrm{~cm}^{-1}$ (C-N stretching), $1070 \mathrm{~cm}^{-1}(\mathrm{C}=\mathrm{C}-\mathrm{H})$ bending), One strong band at $825 \mathrm{~cm}^{-1}$ (para-di-substituted), $559 \mathrm{~cm}^{-1}$ (C-Cl stretching); ${ }^{1} \mathrm{H}-\mathrm{NMR}(126$ MHz, DMSO-d6): $\delta=7.85(1 \mathrm{H} ; 2), 7.76(2 \mathrm{H} ; 5 \& 6), 7.60(1 \mathrm{H} ; 8), 7.35(1 \mathrm{H} ; \mathrm{o}), 7.04(1 \mathrm{H} ; \mathrm{m}), 3.81(3 \mathrm{H} ; \mathrm{p})$ ppm. UV-Vis (DMF): $\lambda_{\max }(\mathrm{nm}): 379,375,366 \mathrm{~nm}$. MS (EI): $\mathrm{m} / \mathrm{z}=309.75\left(\mathrm{M}^{+}\right)$. Elemental analysis: $\mathrm{C}_{17} \mathrm{H}_{12} \mathrm{~N}_{3} \mathrm{ClO}$; Found C 65.01, H 3.01, N 12.97, Calc. 65.92, H 3.90, N 13.57.

\section{7-chloro-3'-(p-N,N-dimethylphenyl)-1'H-pyrazolo[4,3-c]quinoline (4d)}

Prepared from $2 \mathrm{~d}$ as a red-brown solid; m.p. $180-183^{\circ} \mathrm{C}$; $\mathrm{Rf}=0.5$; IR $(\mathrm{KBr}): \mathrm{v}=3424 \mathrm{~cm}^{-1}(\mathrm{~N}-\mathrm{H}$ stretching), $3013 \mathrm{~cm}^{-1}$ (C-H aromatic stretching), $2911 \mathrm{~cm}^{-1}\left(\mathrm{CH}_{3}\right.$ stretching), 4 weak overtone peaks at $2015 \mathrm{~cm}^{-1}$ (mono substituted phenyl), $1667 \mathrm{~cm}^{-1}$ ( $\mathrm{C}=\mathrm{N}$ stretching), $1453 \mathrm{~cm}^{-1}$ ( $\mathrm{C}=\mathrm{C}$ aromatic stretching), $1359 \mathrm{~cm}^{-1}$ (C-H bending), $1260 \mathrm{~cm}^{-1}$ (C-N stretching), $1054 \mathrm{~cm}^{-1}$ (C=C-H bending), One strong band at $807 \mathrm{~cm}^{-1}$ (para-di-substituted), $554 \mathrm{~cm}^{-1}$ (C-Cl stretching); ${ }^{1} \mathrm{H}-\mathrm{NMR}\left(126 \mathrm{MHz}, \mathrm{DMSO}-\mathrm{d}^{6}\right): \delta=7.80$ $(1 \mathrm{H} ; 2), 7.61(2 \mathrm{H} ; 5 \& 6), 7.50(1 \mathrm{H} ; 8), 7.27(1 \mathrm{H} ; \mathrm{o}), 6.77(1 \mathrm{H} ; \mathrm{m}), 2.97(6 \mathrm{H} ; \mathrm{p}) \mathrm{ppm} . \mathrm{UV}-\mathrm{Vis}(\mathrm{DMF}): \lambda_{\max }$ (nm): 392, 378, $367 \mathrm{~nm}$. MS (EI): $\mathrm{m} / \mathrm{z}=322.79\left(\mathrm{M}^{+}\right)$. Elemental analysis: $\mathrm{C}_{18} \mathrm{H}_{15} \mathrm{~N}_{4} \mathrm{Cl}$; Found C 65.74, H 4.01, N 16.80, Calc. C 66.98, H 4.68, N 17.36.

\section{7-chloro-3-(4-nitrophenyl)-1H-pyrazolo[4,3-c]quinoline (4e)}

Prepared from 2e as a pale brown solid; m.p. $200-210^{\circ} \mathrm{C} ; \mathrm{Rf}=0.7 ; \mathrm{IR}(\mathrm{KBr}): \mathrm{v}=3433 \mathrm{~cm}^{-1}(\mathrm{~N}-\mathrm{H}$ stretching), $3020 \mathrm{~cm}^{-1}$ (C-H aromatic stretching), 4 weak overtone peaks at $2000 \mathrm{~cm}^{-1}$ (mono substituted phenyl), $1622 \mathrm{~cm}^{-1}\left(\mathrm{C}=\mathrm{N}\right.$ stretching), $1559 \mathrm{~cm}^{-1}$ ( $\mathrm{N}=\mathrm{O}$ stretching), $1456 \mathrm{~cm}^{-1}(\mathrm{C}=\mathrm{C}$ aromatic stretching), $1355 \mathrm{~cm}^{-1}$ (C-H bending), $1210 \mathrm{~cm}^{-1}$ (C-N stretching), $1120 \mathrm{~cm}^{-1}$ (C=C-H bending), One strong band at $800 \mathrm{~cm}^{-1}$ (para-di-substituted), $553 \mathrm{~cm}^{-1}$ (C-Cl stretching); ${ }^{1} \mathrm{H}-\mathrm{NMR}\left(126 \mathrm{MHz}, \mathrm{DMSO}-\mathrm{d}^{6}\right): \delta=8.40$ $(1 \mathrm{H} ; 2), 8.29(2 \mathrm{H} ; 5 \& 6), 8.05(1 \mathrm{H} ; 8), 8.02(1 \mathrm{H} ; \mathrm{o}), 7.58(1 \mathrm{H} ; \mathrm{m})$ ppm. UV-Vis $(\mathrm{DMF}): \lambda_{\max }(\mathrm{nm})$ : 
405,387,367 nm. MS (EI): $\mathrm{m} / \mathrm{z}=324.72\left(\mathrm{M}^{+}\right)$. Elemental analysis: $\mathrm{C}_{16} \mathrm{H}_{9} \mathrm{~N}_{4} \mathrm{ClO}_{2}$; Found $\mathrm{C} 58.93, \mathrm{H}$ 2.02, N 17.83, Calc. C 59.18, H 2.79, N 17.25.

\section{7-chloro-3-(2-chlorophenyl)-1H-pyrazolo[4,3-c]quinoline (4f)}

Prepared from 2f as a green brown solid; m.p. $184-213^{\circ} \mathrm{C} ; \mathrm{Rf}=0.95 ; \mathrm{IR}(\mathrm{KBr}): \mathrm{v}=3434 \mathrm{~cm}^{-1}(\mathrm{~N}-\mathrm{H}$ stretching), $3011 \mathrm{~cm}^{-1}$ (C-H aromatic stretching), 4 weak overtone peaks at $2078 \mathrm{~cm}^{-1}$ (mono substituted phenyl), $1602 \mathrm{~cm}^{-1}$ ( $\mathrm{C}=\mathrm{N}$ stretching), $1453 \mathrm{~cm}^{-1}$ ( $\mathrm{C}=\mathrm{C}$ aromatic stretching), $1352 \mathrm{~cm}^{-1}$ ( $\mathrm{C}-\mathrm{H}$ bending), $1220 \mathrm{~cm}^{-1}$ (C-N stretching), $1130 \mathrm{~cm}^{-1}$ (C=C-H bending), One strong band at $756 \mathrm{~cm}^{-1}$ (ortho-disubstituted), $555 \mathrm{~cm}^{-1}$ (C-Cl stretching); ${ }^{1} \mathrm{H}-\mathrm{NMR}(126 \mathrm{MHz}, \mathrm{DMSO}-\mathrm{d} 6): \delta=8.38(1 \mathrm{H} ; 2), 8.16(2 \mathrm{H}$; 5\&6), 7.86 (1H;8), 7.49 (1H;m), 7.37 (1H;p) ppm. UV-Vis (DMF): $\lambda_{\max }(\mathrm{nm}): 371,366,360 \mathrm{~nm} . \mathrm{MS}$ (EI): $\mathrm{m} / \mathrm{z}=314.17\left(\mathrm{M}^{+}\right)$. Elemental analysis: $\mathrm{C}_{16} \mathrm{H}_{9} \mathrm{~N}_{3} \mathrm{Cl}_{2}$; found $\mathrm{C} 60.13, \mathrm{H} 2.12, \mathrm{~N}$ 12.92, Calc. $\mathrm{C}$ 61.17, H 2.89, N 13.37.

\section{7-chloro-3-(2-(trifluoromethoxy)phenyl)-1H-pyrazolo[4,3-c]quinolone (4g)}

Prepared from $2 \mathrm{~g}$ as a yellow-green solid; m.p. $150-232^{\circ} \mathrm{C} ; \mathrm{Rf}=0.86 ; \mathrm{IR}(\mathrm{KBr}): \mathrm{v}=3411 \mathrm{~cm}^{-1}(\mathrm{~N}-$ $\mathrm{H}$ stretching), $3023 \mathrm{~cm}^{-1}$ (C-H aromatic stretching), 4 weak overtone peaks at $2033 \mathrm{~cm}^{-1}$ (mono substituted phenyl), $1645 \mathrm{~cm}^{-1}$ (C=N stretching), $1452 \mathrm{~cm}^{-1}\left(\mathrm{C}=\mathrm{C}\right.$ aromatic stretching), $1352 \mathrm{~cm}^{-1}(\mathrm{C}-\mathrm{H}$ bending), $1267 \mathrm{~cm}^{-1}$ (C-O stretching), $1204 \mathrm{~cm}^{-1}$ (C-N stretching), $1153 \mathrm{~cm}^{-1}$ (C-F stretching), $1180 \mathrm{~cm}^{-1}$ $\left(\mathrm{C}=\mathrm{C}-\mathrm{H}\right.$ bending), One strong band at $756 \mathrm{~cm}^{-1}$ (ortho-di-substituted), $552 \mathrm{~cm}^{-1}$ (C-Cl stretching); ${ }^{1} \mathrm{H}-$ NMR (126 MHz, DMSO-d $\left.{ }^{6}\right): \delta=8.38(1 \mathrm{H} ; 2), 8.19(2 \mathrm{H} ; 5 \& 6), 7.87(1 \mathrm{H} ; 8), 7.48(1 \mathrm{H} ; \mathrm{m}), 7.39(1 \mathrm{H} ; \mathrm{p})$ ppm. UV-Vis (DMF): $\lambda_{\max }(\mathrm{nm}): 381,364,360 \mathrm{~nm}$. MS (EI): $\mathrm{m} / \mathrm{z}=363.72\left(\mathrm{M}^{+}\right)$. Elemental analysis: $\mathrm{C}_{17} \mathrm{H}_{9} \mathrm{~N}_{3} \mathrm{ClF}_{3} \mathrm{O}$, Found C 55.90, H 2.11 N 11.30, Calc. C 56.14, H 2.49, N 11.55.

\section{Results and discussions}

The electrochemical synthesis of hydrazone derivatives (4a-g) through dehydrogenative cyclization was conducted in an undivided cell, and the cell was equipped with a graphite electrode as the anode and a platinum plate electrode as the cathode while Tetrabutylammonium tetrafluoroborate (TBATFB) was used as the supporting electrolyte. The electrochemical reactions proceed without oxidizing reagents or transition metal catalysts (Figure 1).

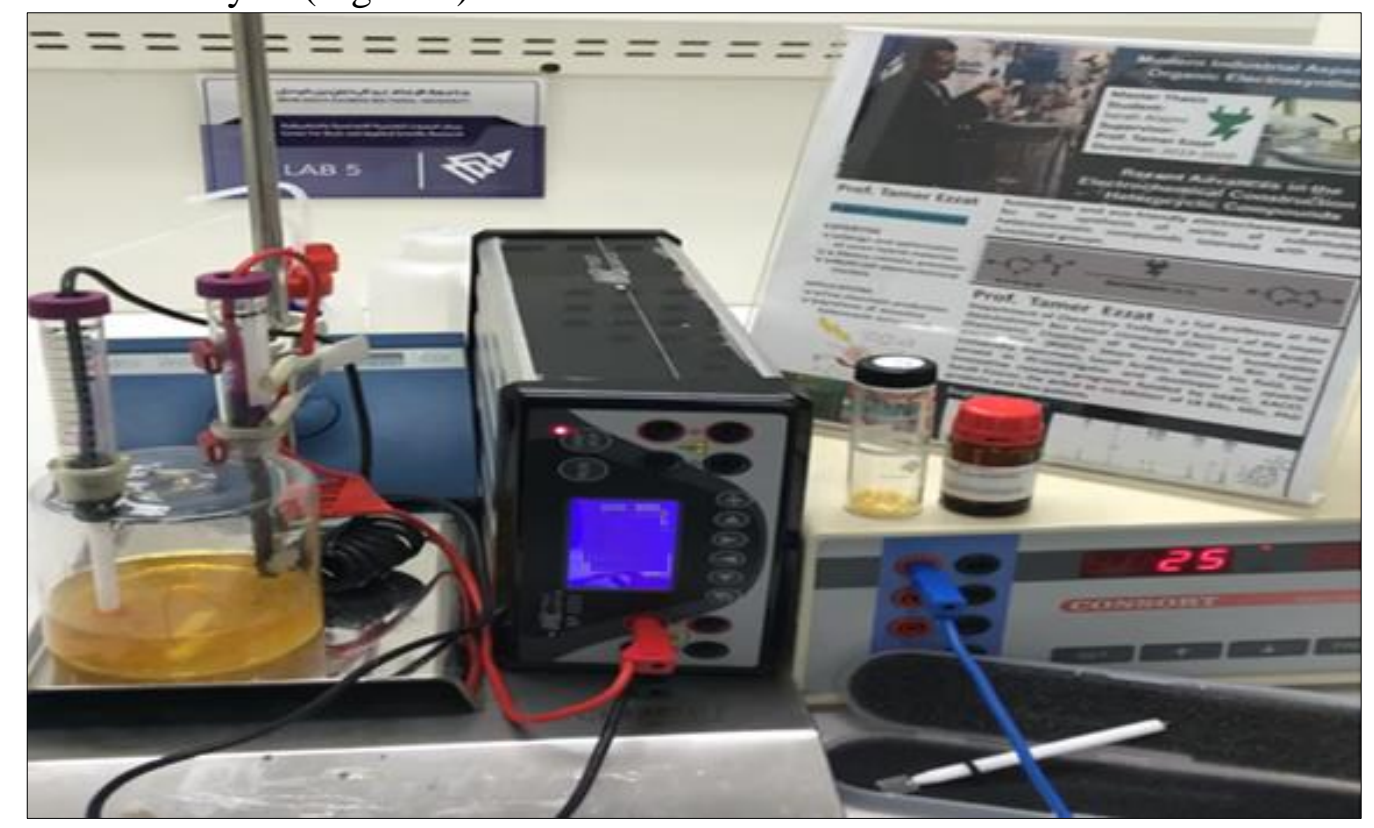

Figure 1. The controlled potential organic electrosynthesis cell design

As explained previously, the reaction can be carried out in two steps to provide the desired cyclic hydrazones (4a-g) within 20-30 min with $40-84 \%$ yields. The first step is chemical condensation of 
linear hydrazones 7-chloro-4-quinolinylhydrazones derivatives (3a-g) and the second step is the electrochemical cyclization (4a-g) in Scheme 1. All linear hydrazones 7-chloro-4-quinolinylhydrazones derivatives formed during all the reactions did not interfere with the cyclization reaction.

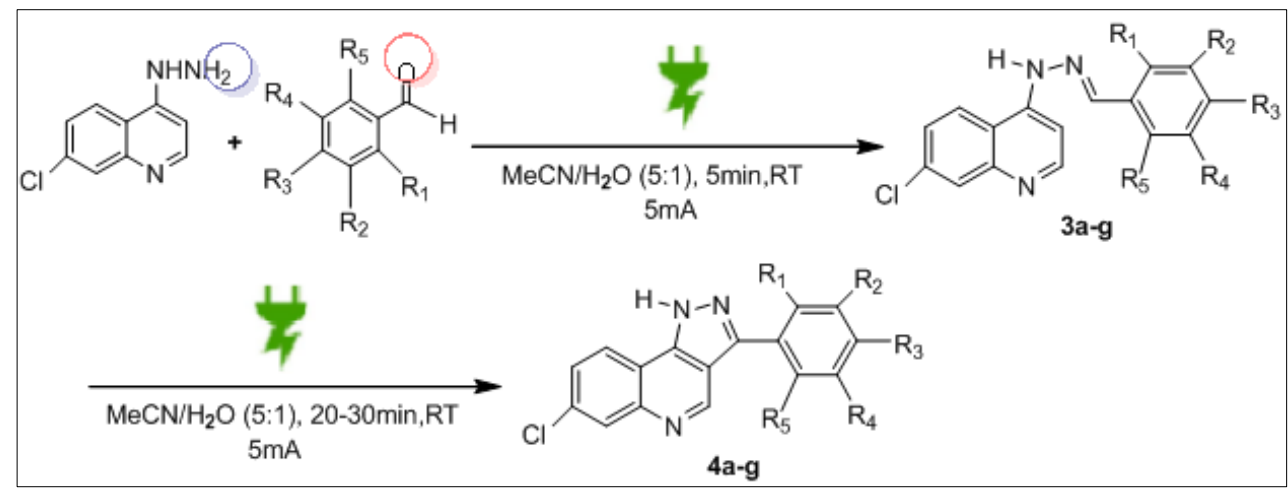

Scheme 1. General scope for the synthesis of cyclic hydrazones (4a-g)

The substrate scope for the synthesis of cyclic hydrazones (4a-g) was then explored Scheme 1. First, the benzene ring of aldehydes (2a-g) at the para-position could be substituted with electron donating groups such as methyl (2b), methoxy (2c), dimethyl amine (2d) and with electron-withdrawing substituents such as nitro (2e). Second, substituted groups at the ortho-position such as chloro (2f) and trifluoro methoxy $(\mathbf{2 g})$ have been used.

The efficiency of the reaction of the electron-deficient substrates was decreased due to the possibility of the difficulty in cyclizing the electrophilic C-radical onto the $N$-phenyl ring.

Hydrazones bearing methyl (2b), methoxy (2c), and dimethyl amine (2d) groups reacted in a smooth way to afford the desirable cyclic products in higher yields (70-84\%) but, the reaction of nitro-derived hydrazone (2e) afforded 4e in lower yield (40\%) Scheme 2.

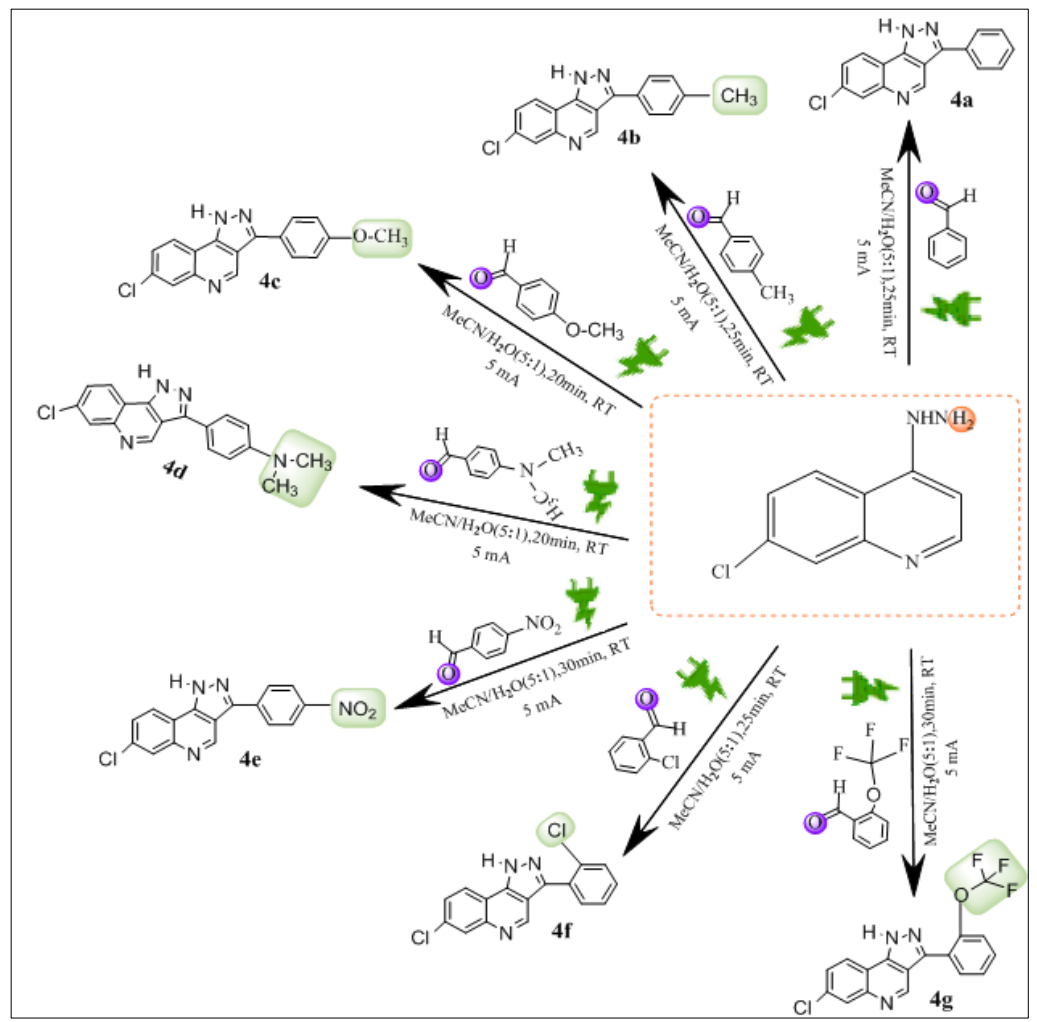

Scheme 2. Pathways for the synthesis of pyrazolo[4,3-c]quinoline derivatives 
Our experiments were carried out in the undivided cell, and the applied potential to the working electrode was $2.5 \mathrm{~V}$. The electrodes were placed in an undivided cell as close to each other as possible to reduce cell resistance. Platinum electrode selected as the working electrode since it has been proven that it has a good activity toward the organic electrosynthesis [29]. The reaction proceeded at the cathode graphite.

For optimal results, stirring can be introduced to increase mass transfer, however, since no laminar flow over the electrode surface is obtained, such setups are not considered hydrodynamic electrodes.

In this setup, the maximum cyclic hydrazones (4a-g) concentration was reached within the first 20 min as described in (Table 1). The course of the reaction was followed up via TLC each ten minutes. After $30 \mathrm{~min}$, the final concentration was already reached. The experiment was repeated and blocking the surface of the electrode was possible.

For further investigation of the resulted cyclic hydrazones (4a-g), the measurements of UV-VIS spectroscopy were performed on the products and were recorded in DMF Figure 2. UV spectra show an absorption band at (361-366) $\mathrm{nm}$ in all aldehyde's spectra.

Table 1. The Reaction Yields of Cyclic Hydrazones (4a-g) Formation

\begin{tabular}{|c|c|c|c|c|}
\hline Entry & Substituents & Reaction Time & $\begin{array}{c}\text { Yield } \\
(\%)\end{array}$ & MP $\left(\mathrm{C}^{0}\right)$ \\
\hline $\mathbf{4 a}$ & $\mathrm{R}_{1}=\mathrm{R}_{2}=\mathrm{R}_{3}=\mathrm{R}_{4}=\mathrm{R}_{5}=\mathrm{H}$ & $25 \mathrm{~min}$ & $68 \%$ & $224-234$ \\
\hline $\mathbf{4 b}$ & $\mathrm{R}_{3}=\mathrm{CH}_{3} ; \mathrm{R}_{1}=\mathrm{R}_{2}=\mathrm{R}_{4}=\mathrm{R}_{5}=\mathrm{H}$ & $25 \mathrm{~min}$ & $70 \%$ & $210-212$ \\
& & & & \\
\hline $\mathbf{4 c}$ & $\mathrm{R}_{3}=\mathrm{OCH}_{3} ; \mathrm{R}_{1}=\mathrm{R}^{2}=\mathrm{R}^{4}=\mathrm{R}^{5}=\mathrm{H}$ & $20 \mathrm{~min}$ & $80 \%$ & $175-195$ \\
\hline $\mathbf{4 d}$ & $\mathrm{R}_{3}=\mathrm{N}\left(\mathrm{CH}_{3}\right)_{2} ; \mathrm{R}_{1}=\mathrm{R}_{2}=\mathrm{R}_{4}=\mathrm{R}_{5}=\mathrm{H}$ & $20 \mathrm{~min}$ & $84 \%$ & $180-183$ \\
\hline $\mathbf{4 e}$ & $\mathrm{R}_{3}=\mathrm{NO}_{2} ; \mathrm{R}_{1}=\mathrm{R}_{2}=\mathrm{R}_{4}=\mathrm{R}_{5}=\mathrm{H}$ & $30 \mathrm{~min}$ & $40 \%$ & $200-210$ \\
\hline $\mathbf{4 f}$ & $\mathrm{R}_{1}=\mathrm{Cl}_{2} \mathrm{R}_{2}=\mathrm{R}_{3}=\mathrm{R}_{4}=\mathrm{R}_{5}=\mathrm{H}$ & $25 \mathrm{~min}$ & $67 \%$ & $184-213$ \\
\hline $\mathbf{4 g}$ & $\mathrm{R}_{1}=\mathrm{OCF}_{3} ; \mathrm{R}_{2}=\mathrm{R}_{3}=\mathrm{R}_{4}=\mathrm{R}_{5}=\mathrm{H}$ & $30 \mathrm{~min}$ & $64 \%$ & $150-232$ \\
\hline
\end{tabular}

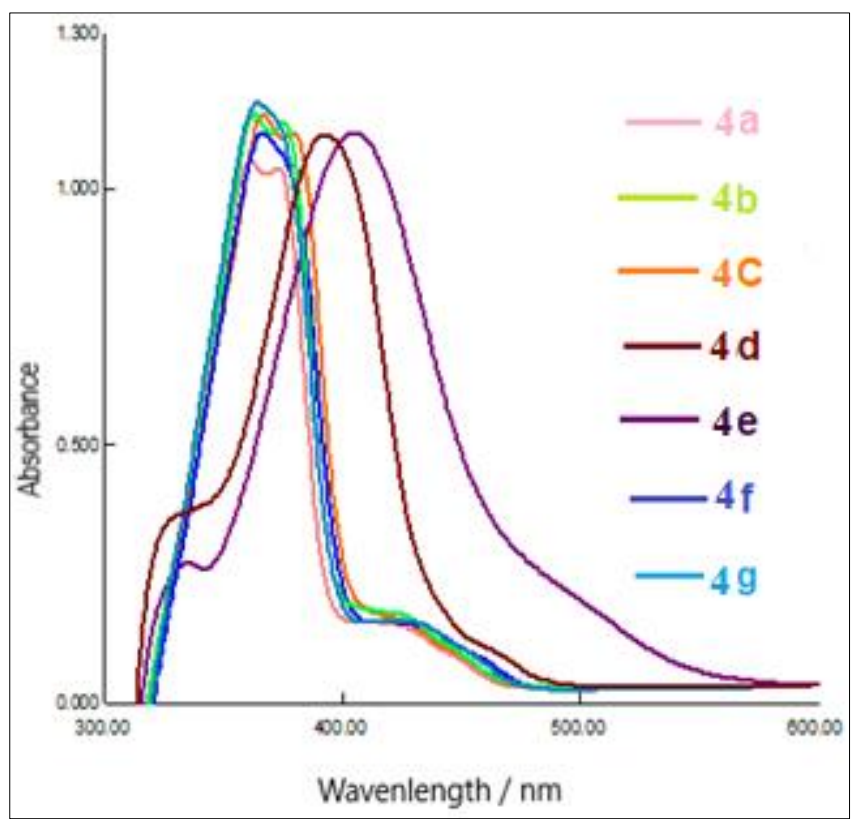

Figure 2. UV absorption spectra for cyclic hydrazone derivatives (4a-g) recorded in DMF

For further verification, the measurements of FT-IR spectra were performed on the cyclic hydrazone derivatives (4a-g) and were recorded in a spectral range between 4000 and $400 \mathrm{~cm}^{-1}$. The IR spectra displayed a strong band at $3400 \mathrm{~cm}^{-1}$ attributed to the $\mathrm{NH}$ stretching vibration. The noticed vibrations in the region $3000 \mathrm{~cm}^{-1}$ were specified to aromatic $\mathrm{CH}$ stretching; in addition, the band of phenyl ring was observed at $2000 \mathrm{~cm}^{-1}$. The $\mathrm{C}=\mathrm{C}$ aromatic stretching was observed at $1450 \mathrm{~cm}^{-1}$. The band at $1350 \mathrm{~cm}^{-1}$ 
can be assigned to $\mathrm{CH}$ bending, whereas the band at $1200 \mathrm{~cm}^{-1}$ was observed to $\mathrm{C}-\mathrm{N}$ stretching. The noticed vibrations in the region $1050-1100 \mathrm{~cm}^{-1}$ were assigned to $\mathrm{C}=\mathrm{C}-\mathrm{H}$ bending. In the IR spectra of all cyclic hydrazone derivatives (4a-g), we observed the apparition of a strong band at $1600 \mathrm{~cm}^{-1}$ and it was assigned to the stretching vibration of $\mathrm{C}=\mathrm{N}$.

\section{Mechanism}

In the following step, efforts were made to verify the reaction mechanism. Because of previous results and reports [2], a possible mechanism of the electrochemical synthesis of hydrazones through the dehydrogenative cyclization of the linear hydrazones 7-chloro-4-quinolinylhydrazones derivatives was suggested via using the reaction of hydrazine; 7-chloro-3-phenyl-1H-pyrazolo[4,3-c]quinoline (4a) as an example Scheme 3. The structural features and new mechanism have been covered by this work to speed up the reaction. Although the synthesis of hydrazone was a direct condensation Scheme 1, the reaction was not reversible in aqueous media.

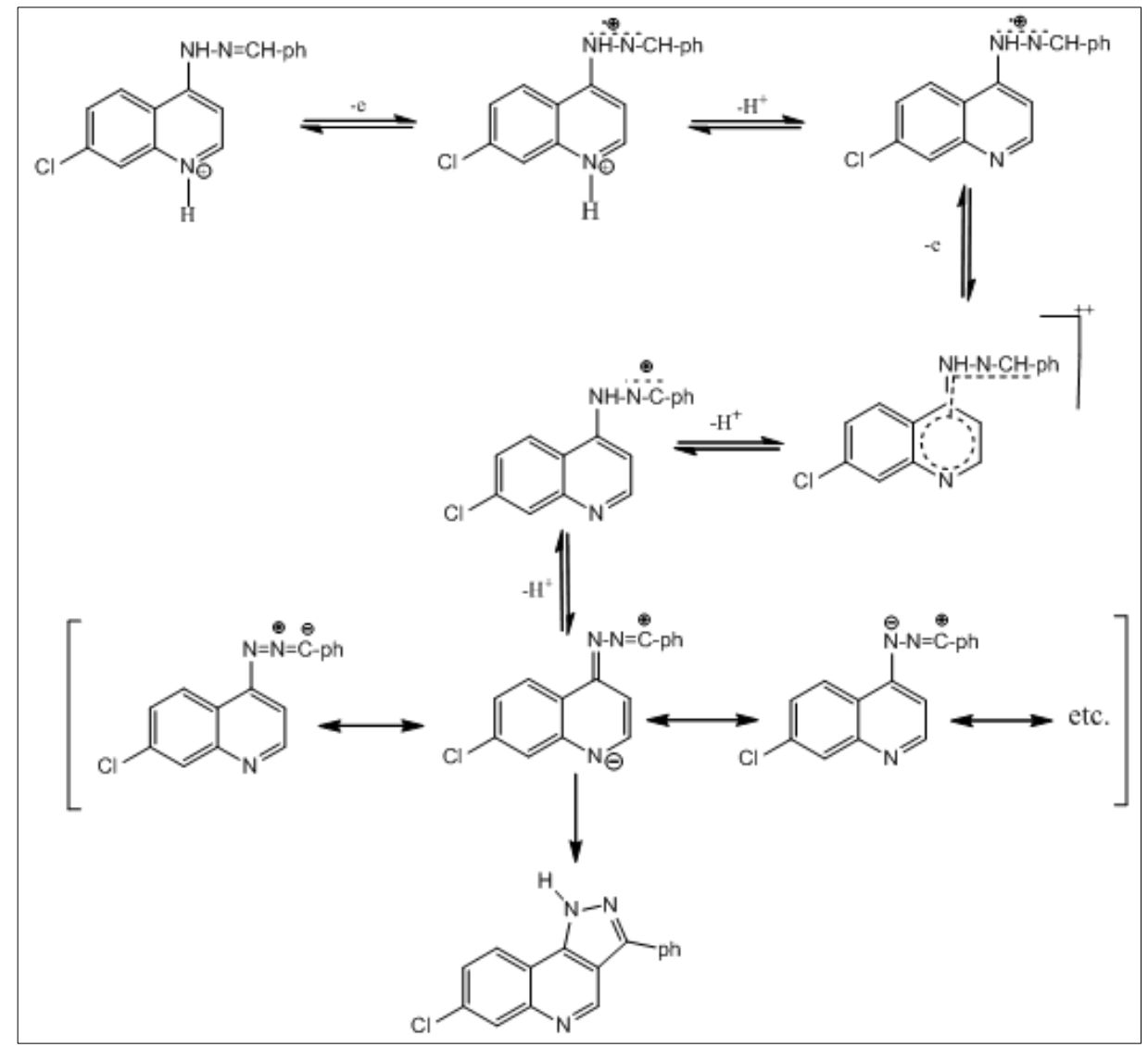

Scheme 3. Proposed mechanism for electrochemical dehydrogenative cyclization

\section{Conclusions}

In conclusion, we have developed an efficient electrochemical system for cyclic hydrazone (4a-g) formation of the linear hydrazones 7-chloro-4-quinolinylhydrazones derivatives (3a-g) by the straightforward dehydrogenative in a simple undivided cell. The electrosynthetic pathway of the cyclic hydrazone formation reaction of hydrazine with aromatic aldehydes has been investigated. The under-standing of the reaction and the improvement of the outcome of the transformation are necessary to avoid the degradation of the formed intermediates, and that is for further verification in the mechanism. This electrochemical process provides access to fused heterocycles in a straightforward and clean way. Since the electrochemical construction of aromatic heterocycles represents a major part of drugs, it deserves more attention. 
Acknowledgments: This work was realized in a close collaboration with the laboratory of Prof. Dr. Tamer Ezzat: Director of Renewable and Sustainable Research Unit-Basic and Applied Scientific Research Center; Imam Abdulrahman Bin Faisal University, Saudi Arabia.

\section{References}

1.WIEBE, A., GIESHOFF, T., MÖHLE, S., RODRIGO, E., ZIRBES, M., WALDVOGEL, S.R., Electrifying Organic Synthesis, Angew. Chemie - Int. Ed., 57(20), 2018, 5594-5619.

2.MÖHLE, S., ZIRBES, M., RODRIGO, E., GIESHOFF, T., WIEBE, A., WALDVOGEL, S.R., Modern Electrochemical Aspects for the Synthesis of Value-Added Organic Products, Angew. Chemie - Int. Ed., 57(21), 2018, 6018-6041.

3.FRANCKE, R., LITTLE, R.D., Redox Catalysis in Organic Electrosynthesis: Basic Principles and Recent Developments, Chem. Soc. Rev., 43(8), 2014, 2492-2521.

4.GHOSH, M., SHINDE, V.S., RUEPING, M., A Review of Asymmetric Synthetic Organic Electrochemistry and Electrocatalysis: Concepts, Applications, Recent Developments and Future Directions, Beilstein J. Org. Chem., 15(1), 2019, 2710-2746.

5.SHATSKIY, A., LUNDBERG, H., KÄRKÄS, M.D., Organic Eelectrosynthesis: Applications in Complex Molecule Synthesis, ChemElectroChem, 6(16), 2019, 4067-4092.

6.FRONTANA-URIBE, B.A., LITTLE, R.D., IBANEZ, J.G., PALMA, A., VASQUEZ-MEDRANO, R., Organic Electro-synthesis: A Promising Green Methodology in Organic Chemistry, Green Chem., 12(12), 2010, 2099-2119.

7.NEWMAN, S.G., JENSEN, K.F., The Role of Flow in Green Chemistry and Engineering, Green Chem., 15(6), 2013, 1456-1472.

8.YANGYE, J., KUN, X., CHENGCHU, Z., Use of Electrochemistry in the Synthesis of Heterocyclic Structures, Chem. Rev., 118(9), 2018, 4485-4540.

9.SAYYAR, R., MAKAREM, S., MIRZA, B., Organic Electrosynthesis as a New Facile and Green Method for One-pot Synthesis of Nanosized Particles of Octahydro-imidazo [1, 2-a] quinolin-6-one Derivatives via a Multicomponent Reaction, J. Heterocycl. Chem., 56(6), 2019, 1839-1843.

10.HUANG, C., QIAN, X.Y., XU, H.C., Continuous-Flow Electrosynthesis of Benzofused S-Heterocycles by Dehydrogenative C-S Cross-Coupling, Angew. Chemie - Int. Ed., 58(20), 2019, 6650-6653. 11.MARELlA, A., TANWAR, O.P., SAHA, R., ALI, M.R., SRIVASTAVA, S., AKHTER, M., SHAQUIQUZZAMAN, M., ALAM, M.M., QUINOLINE: A Versatile Heterocyclic, Saudi Pharm. J., 21(1), 2013, 1-12.

12.BISPO, M.D.L.F., DE ALCANTARA, C.C., DE MORAES, M.O., DO Ó PESSOA, C., RODRIGUES, F.A.R., KAISER, C.R., WARDELL, S.M.S.V., WARDELL, J.L., DE SOUZA, M.V.N., A New and Potent Class of Quinolone Derivatives Against Cancer, Monatsh. Chem., 146(12), 2015, 2041-2052.

13.AFZAL, O., KUMAR, S., HAIDER, M.R., ALI, M.R., KUMAR, R., JAGGI, M., BAWA, S., A Review on Anticancer Potential of Bioactive Heterocycle Quinoline, Eur. J. Med. Chem., 97(1), 2015, 871-910.

14.NKOSI, S.M., PhD Thesis, Synthesis of Novel Quinoline Derivatives and their Cytotoxicity in A549 Lung Cancer Cells, Durban University of Technology, 2017, 151pp

15.LIU, X.H., FANG,Y.M., XIE, F., ZHANG, R.R., SHEN, Z.H., TAN, C.X., WENG, J.Q., XU,T.M., HUANG, H.Y., Synthesis and in Vivo Fungicidal Activity of Some New Quinoline Derivatives Against Rice Blast, Pest Manag. Sci., 73(9), 2017, 1900-1907.

16.B.SURESHKUMAR， Y.S.MARY， C.Y.PANICKER， S.SUMA， S.ARMAKOVIĆ， S.J. ARMAKOVIĆ, et al. Quinoline Derivatives As Possible Lead Compounds for Anti-malarial Drugs: Spectroscopic, DFT and MD Study, Arab. J. Chem., 13(1), 2020, 632-48.

17.CHANQUIA, S.N., LARREGUI, F., PUENTE, V., LABRIOLA, C., LOMBARDO, E., GARCÍA LIÑARES, G., Synthesis and Biological Evaluation of New Quinoline Derivatives as Antileishmanial and Antitrypanosomal Agents, Bioorg. Chem., 83, 2019, 526-534. 
18.Le.T.D., PHAM, N.N., NGUYEN, T.C., Preparation and Antibacterial Activity of Some New 4-(2Heterylidenehydrazinyl)-7-chloroquinoline Derivatives, J. Chem., 2018, 2018.

19.WEI, C.X., DENG, X.Q., CHAI, K.Y., SUN, Z.G., QUAN, Z.S., Synthesis and Anticonvulsant Activity of 1-formamide-triazolo [4, 3-a] quinoline Derivatives, Arch. Pharm. Res., 33(5), 2010, 655662.

20.JAFARI, F., BAGHAYI, H., LAVAEE, P., HADIZADEH, F., SOLTANI, F., MOALLEMZADEH, H., MIRZAEI, S., ABOUTORABZADEH, S.M., GHODSI, R., Design, Synthesis and Biological Evaluation of Novel Benzo-and Tetrahydrobenzo-[h] quinoline Derivatives As Potential DNA-intercalating Antitumor Agents, Eur. J. Med. Chem., 164, 2019, 292-303.

21.EL-BEHERY, M., EL-TWIGRY, H., Synthesis, Magnetic, Spectral, and Antimicrobial Studies of $\mathrm{Cu}$ (II), Ni (II) Co (II), Fe (III), and UO2 (II) Complexes of a New Schiff Base Hydrazone Derived From 7-chloro-4-hydrazinoquinoline, Spectrochim. Acta - Part A Mol. Biomol. Spectrosc., 66(1), 2007, 2836.

22.ERGUC, A., ALTINTOP, M.D., ATLI, O., SEVER, B., ISCAN, G., GORMUS, G, OZDEMIR, A., Synthesis and Biological Evaluation of New Quinoline-Based Thiazolyl Hydrazone Derivatives as Potent Antifungal and Anticancer Agents, Lett. Drug. Des. Discov., 15(2), 2018, 193-202.

23.CANDÉA, A.L.P., FERREIRA, M. DE L., PAIS, K.C., CARDOSO, L. N. D. F., KAISER, C. R., HENRIQUES, M. DAS G. M. D. O., LOURENÇO, M. C. S., BEZERRA, F. A. F. M., DE SOUZA, M. V. N., Synthesis and Antitubercular Activity of 7-chloro-4-quinolinylhydrazones Derivatives, Bioorg. Med. Chem. Lett., 19(22), 2009, 6272-6274.

24.MONTENEGRO, R.C., LOTUFO, L.V., DE MORAES, M.O., PESSOA, C.D., RODRIGUES, F.A.R., DE LIMA FERREIRA BISPO, M., NOGUEIRA DE FARIA CARDOSO, L., KAISER, C.R., VINICIUS NORA DE SOUZA, M., Synthesis and Antitumoral Evaluation of 7-chloro-4-quinolinylhydrazones Derivatives, J. Med. Chem., 7(6), 2011, 599-604.

25.COIMBRA, E.S., ANTINARELLI, L.M.R.,DA SILVA, A.D., BISPO, M.L.F., KAISER, C. R., DE SOUZA, M. V. N., 7-Chloro-4-quinolinyl Hydrazones: A Promising and Potent Class of Antileishmanial Compounds, Chem. Biol. Drug Des., 81(5), 2013, 658-665.

26.FERREIRA, M.D., GONÇALVES, R.S., CARDOSO, L.N., KAISER, C.R., CANDÉA, A.L., HENRIQUES, M.D., LOURENÇO, M., BEZERRA, F.A., DE SOUZA, M.V., Synthesis and antitubercular activity of heteroaromatic isonicotinoyl and 7-chloro-4-quinolinyl hydrazone derivatives, Sci. World J., 10, 2010,1347-1355.

27.DUVAL, A.R., CARVALHO, P.H., SOARES, M.C, GOUVÊA, D.P., SIQUEIRA, G.M., LUND, R.G., CUNICO, W., 7-Chloroquinolin-4-yl Arylhydrazone Derivatives: Synthesis and Antifungal Activity, Sci. World J., 11, 2011, 1489-1495.

28.ATTIA, A., ABD EL-SALAM, O. I., YOUSSEF, T. E., Electron and Hydrogen Transfer Reductions of some 2,4-Disubstituted Pyridines, Indian J Hetero Chem., 8(4), 1999, 325- 328.

29.KUMA, S., SHARMA, L. K., SINGH, R. K. P., Electroinduced Aldol Condensation at Platinum Electrode. J. Indian Chem. Soc., 83(11), 2006, 1160-1162.

$\overline{\text { Manuscript received: } 06.11 .2020}$ 